objectives and priorities, he was appointed director of the Microbiological Research Department in January 1946. His first tasks were to recruit staff and to plan new laboratories. Neither was easy, but Henderson threw himself into both with determination, recruiting staff one by one on the basis of their individual research potential rather than their scientific discipline or the specific requirements of the research programme. In June 1951 he and his staff moved into the new laboratory, specifically designed for the safe production and study of microorganisms, including pathogens, on a large laboratory scale. Shortly afterwards, he recommenced publishing papers, sometimes alone, as when the "Henderson apparatus" for exposing animals to aerosols was described in detail $(J$. Hygiene, 50, 53; 1952), and also with colleagues. By 1954, he was able to report good progress in person to the Royal Society (Proc. Roy. Soc., B, 143, $192 ; 1955)$. In the following year he had sufficient confidence in his staff and in the self generating momentum of the research programme to take a year's sabbatical leave. Since no other laboratory could offer better facilities for studies on respiratory infection, he spent it at the bench in his own laboratory. The results were published in a short series of papers in 1956.

Henderson continued to expand the scope and extent of research, and his efforts to establish a "centre for microbiological research" with emphasis on the prevention or curtailment of the infectious process rather than on therapy and treatment were acknowledged by his admission as a Commander of the Most Excellent Order of the Bath (1957). By 1959, the establishment had acquired a national reputation and in some spheres an international one, and Henderson's personal contribution was recognized by his election as a Fellow of the Royal Society. Henderson spent the next few years trying to balance up his research team and to open up leads to civil application from the defence research done in the establishment, but the strain of his many battles was beginning to tell. Hypertension was mounting steadily and he was increasingly subject to attacks of acute respiratory infection during the winter. By 60 , he, who had never understood why men retire early, was eagerly seeking a successor, and no one was more pleased than he when Dr C. E. G. Smith was appointed in August 1964. By the end of the year he had completed the handover, and withdrawing wholly and tactfully from "management" and "policy" he went back to the laboratory. At about the same time he completed his two years' term as President of the Society of General Microbiology.

Back at the bench, Henderson sought to apply to viral aerosols the same quantitative methods that he had used fifteen years earlier with bacteria. He became increasingly interested in the sequence of pathological events and showed the rapidity with which a respiratory infection with Semliki Forest virus reached the brain of the hamster (Brit. J. Exp. Pathol., 68, 228; 1967). He made good recoveries from several minor thromboses, but another in July 1967 brought his active work to an end. He was in and out of hospital several times in the ensuing year, but his condition slowly deteriorated and he died in his sleep on August 16 this year.

\section{Professor V. B. Stockmann}

Professor Vladimir Borisovich Stockmann, who was born in Moscow on March 10, 1909, devoted his whole career to physical oceanography. He began in the State Oceanographic Institute in 1931 as a laboratory assistant, but was quickly promoted to the senior research position. In 1934 he organized the Laboratory of Physical Oceanography in Bakou on the Caspian Sea. In 1938 the Faculty of Physies of the University of Leningrad awarded hirn the first scientific degree (candidate of sciences) honoris causa. Since 1939 he has worked in the Institute of
Theoretical Geophysics and in the Arctic Research Institute. When, in 1943, the USSR Academy of Sciences established the Laboratory of Oceanology, he moved there and worked in this laboratory (later reorganized into the Institute of Oceanology) until his sudden death on June 14 this year. He received his DSc degree in 1943 .

Stockmann's most important contribution was to the theory of ocean currents. In the early forties he drew attention to the importance of the wind stress vorticity in determining circulation patterns in the ocean. Applying this principle to the major features of the ocean circulation, he succeeded in developing the theory of the well known equatorial countercurrents in the oceans.

In 1946 he developed a now method for studying general ocean circulation - the method of total flows-used later by many other scientists. On numerous examples he demonstrated the effectiveness of the practical application of this method and proposed various ways of overcoming some of its natural restrictions (analogy with elastic membranes, density model, and so on).

Very early in his scientific career he became interested in oceanic turbulence and mixing processes. He paid particular attention to developing indirect methods for evaluation of eddy viscosity and eddy diffusivity in the ncean and to the theory of T,S-diagrams. During his last years he gave much of his energy to the planning and implementation of multi-ship and multi-buoy operations for the continuous study of oceanic turbulence and its spectral characteristics.

In the Institute of Oceanology, Stockmann built up a strong research team of young and enthusiastic scientists interested in the theoretical aspects of modern oceanology. In 1946 this group was administratively organized as the Laboratory of Marine Hydrodynamies (later Department of Theoretical Studies) and Stockmann remained its head until he died.

Erratum. In the communication "Molecular Pathology of Human Haemoglobin" by M. F. Perutz and H. Lehmann (Nature, 219, 902; 1968) the third sentence of the seventh paragraph on page 903 should read "This means that in a 0.65 per cent solution of haemoglobin Kansas half the molecules would be dissociated into dimers, compared with about one-twenty-sixth in a similar solution of haemoglobin A." The word "molecules" at the end of the fifth line of the second paragraph should read "globin chains". The footnote marked by an asterisk in Table 1 should read personal communication from $J$. Greer; that marked by a dagger should read Opfell, R. W., Lorkin, P. A., and Lehmann, H., J. Med. Genet., 6. 257 (1968) (in the press). The asterisk by Santa Ana in column 2 of the table should, in fact, be a dagger. Reference 57 should read Biochim. Biophys. Acta, 140, $231 ; 1967)$.

Frratum. In the article "Molecular Biology Comes of Age" (Nature, 219, 825; 1968) reference 13 on page 829 should refer to R. R. Traut, and not P. R. Traub.

\section{CORRESPONDENCE}

\section{Naming the Units}

Srr,-Re the letter "Naming the Units" in the issue of August 17 (Nature, 219, 765; 1968), and in case no one else has pointed this out, in French a unit of $10^{9}$ is un milliard, and one of $10^{18}$ is un trillion.

Yours, etc.,

A. LodGe

31 Swanley Lane,

Swanley, Kent. 